\title{
СТАН КЛІТИННОГО ТА ГУМОРАЛЬНОГО ІМУНІТЕТУ, ЦИТОКІНОВИЙ СТАТУС І МЕДІАТОРИ ЗАПАЛЕННЯ ПРИ АТОПІЧНОМУ ДЕРМАТИТІ В ДІТЕЙ
}

СТАН КЛІТИННОГО ТА ГУМОРАЛЬНОГО ІМУНІТЕТУ, ЦИТОКІНОВИЙ СТАТУС І МЕДІАТОРИ ЗАПАЛЕННЯ ПРИ АТОПІЧНОМУ ДЕРМАТИТІ В ДІТЕЙ. У даній статті наведено результати імунологічного обстеження дітей з атопічним дерматитом та практично здорових дітей віком від 1 до 18 років. Виявлено зміни та проведено оцінку показників клітинної і гуморальної ланок імунітету, цитокінового статусу та рівня сироваткових імуноглобулінів, що залежали від ступеня тяжкості клінічного перебігу атопічного дерматиту. Оцінку тяжкості перебігу захворювання проводили напівкількісним методом за індексом SCORAD (Scoring of Atopik Dermatitis). Обґрунтовано доцільність і перспективу застосування імунологічного обстеження у дітей з атопічним дерматитом для оцінки динаміки перебігу захворювання.

СОСТОЯНИЕ КЛЕТОЧНОГО И ГУМОРАЛЬНОГО ИММУНИТЕТА, ЦИТОКИНОВЫЙ СТАТУС И МЕДИАТОРЫ ВОСПАЛЕНИЯ ПРИ АТОПИЧЕСКОМ ДЕРМАТИТЕ У ДЕТЕЙ. В данноЙ статье представленЫ резУЛЬтатЫ иммУнологИческого обследования детей с атопическим дерматитом и детей контрольной группы в возрасте от 1 до 18 лет. Выявлены изменения и проведена оценка показателей клеточного и гуморального звеньев иммунитета, цитокинового статуса и уровня сывороточных иммуноглобулинов, которые зависели от степени тяжести клинического течения атопического дерматита. Оценку тяжести течения атопического дерматита проводили полуколичественным методом по индексу SCORAD (Scoring of Atopik Dermatitis). Обоснованы целесообразность и перспектива применения иммунологического обследования у детей с атопическим дерматитом для оценки динамики течения заболевания.

INDICATORS OF CELLULARAND HUMORAL IMMUNITY, CYTOKINE STATUS AND INFLAMMATORY MEDIATORS IN CHILDREN WITH ATOPIC DERMATITIS. This article presents the results of immunological examination of children with atopic dermatitis and control group of children age from 1 to 18 years. The changes in indicators of cellular and humoral immunity, cytokine status and serum immunoglobulins were found and evaluated, which dependent on the severity of the clinical course of atopic dermatitis. Evaluation of severity of atopic dermatitis was conducted by semiquantitative index SCORAD (Scoring of Atopik Dermatitis). Expediency and perspective of application immunological examination in children with atopic dermatitis is substantiated in this research to assess dynamics of the disease.

Ключові слова: атопічний дерматит, імунологічне обстеження, клітинний і гуморальний імунітет, цитокіновий статус, сироваткові імуноглобуліни.

Ключевые слова: атопический дерматит, иммунологическое обследование, клеточный и гуморальный иммунитет, цитокиновый статус, сывороточные иммуноглобулины.

Key words: atopic dermatitis, immunological examination, cellular and humoral immunity, cytokine status, serum immunoglobulins.

ВСТУп. Останні десятиліття відзначаються значним зростанням поширеності алергічних захворювань в усьому світі [1, 7]. У структурі алергічних захворювань особливе місце посідає атопічний дерматит, що становить від 50 до $75 \%$, він $є$ одним із найчастіших та перших проявів алергії, нерідко трансформується надалі в інші орорми алергії, суттєво знижує якість життя дітей незалежно від віку, потребує тривалого та етапного лікування і реабілітації [1-3]. У різних країнах на атопічний дерматит хворіють від 10 до 20 \% дітей [5]. Шкіра при атопічному дерматиті - це не тільки «дзеркало атопії», але й «еntry point» (вхідні ворота) для наступних системних алергічних захворювань [4]. Атопічний дерматит розглядається як дебют «алергічного маршу» в дітей і головний фрактор ризику формування респіраторної алергії в подальшому $[4,7]$. Доведено патофрізіологічний зв'язок між тяжким перебігом атопічного дерматиту в дітей, бронхіальною астмою та алергічним ринітом, що становить так звану алергічну (атопічну) тріаду [6, 8].

У механізмах патогенезу і розвитку атопічного дерматиту важливу роль відіграють порушення синтезу ряду речовин та фрункції визначених клітин: 1) порушення синтезу білків, що відповідають за цілісність епідермального бар'єру; 2) імунні порушення зі змінами балансу між окремими субпопуляціями лімсоцитів, які синтезують відповідні цитокіни; 3) генетична схильність, що реалізується під впливом зовнішніх фракторів ризику [3, 5]. Незважаючи на підвищений інтерес дослідників у сфері вивчення генетичних і патофрізіологічних аспектів атопічного дерматиту, етіопатогенез даного захворювання ще повністю не ясний [3].

У зв'язку з цим, перспективним напрямком досліджень залишається вивчення особливостей імунних механізмів формування атопічного дерматиту, а саме: показників клітинного і гуморального імунітету, цитокінового статусу, що $є$ особливо актуальними в наш час $[5,7]$.

Мета роботи - вдосконалити діагностику атопічного дерматиту в дітей на основі оцінки змін показників імунологічного статусу залежно від ступеня тяжкості перебігу захворювання.

МАТЕРІАЛИ ТА МЕТОДИ. У процесі виконання науково-дослідної роботи було обстежено 128 дітей, хворих на атопічний дерматит, та 40 дітей контрольної групи віком від 1 до 18 років. Усім дітям були проведені загальноклінічні методи дослідження: оцінка скарг, анамнестичних даних, об'єктивного статусу пацієнтів із визначенням показників фрізичного розвитку, загальні клініко-лабораторні й біохі- 
мічні, імунологічні, алергологічні, інструментальні методи дослідження, такі, як УЗД шкіри і дерматоскопія. Імунологічне обстеження включало оцінку показників клітинної та гуморальної ланок імунітету із визначенням концентрації субпопуляцій лімфоцитів $\left(\mathrm{CD}_{3}, \mathrm{CD}_{4}, \mathrm{CD}_{8}, \mathrm{CD}_{16}, \mathrm{CD}_{19}\right)$ методом проточної цитофрлюориметрії, сироваткових імуноглобулінів ( $\lg \mathrm{A}, \lg \mathrm{E}, \lg \mathrm{G})$, показників цитокінового статусу - інтерлейкінів (IL-2, IL-4, IL-6, IL-10), INF- $\gamma$ та рівня гістаміну сироватки крові методом імуноферментного аналізу. Оцінку тяжкості перебігу атопічного дерматиту проводили напівкількісним методом за індексом SCORAD (Scoring of Atopik Dermatitis), який розробила Європейська робоча група експертів [8]. Шкала SCORAD передбачає бальну систему оцінки поширеності уражень, шести об'єктивних (еритема/гіперемія, набряк/інтенсивність папул, мокнуття/ кірки, екскоріація, ліхеніфрікація/лущення, сухість шкіри), кожен з яких оцінюють від 0 до 3 балів, і двох суб'єктивних (свербіж і порушення сну) симптомів, кожен з яких оцінюють від 0 до 10 балів, які заносять в оцінювальний аркуш. Оцінки виставляють у спеціальній таблиці, на їх підстав розраховують загальний індекс SCORAD $[7,8]$ :

SCORAD $=\mathrm{A} / 5+7 \times \mathrm{B} / 2+\mathrm{C}$,

де A - площа ураження шкіри у відсотках, визначена за правилом дев'яток;

В - сума балів об'єктивних ознак;

C - сума балів суб'єктивних ознак.

Статистичну обробку матеріалу здійснювали за допомогою стандартних алгоритмів варіаційної статистики, для розрахунків використовували комп'ютерні програми Excel (Microsoft Office, USA) i Statistica 6.0 та on-line калькулятор SISA (Simple Interactive Statistical Analysis), розраховували t-критерій Стьюдента або критерій х2 (різницю вважали вірогідною при $p \leq 0,01$ або $p<0,05$ ).

РЕЗУЛЬТАТИ ДОСЛІДЖЕННЯ ТА ЇХ ОБГОВОРЕННЯ Розподіл відповідно до вікових форм атопічного дерматиту становив: малюкова фрорма - 15,63 \%, дитяча - 54,69 \%, підліткова - 29,69 \%. Розподіл за ступенем тяжкості перебігу захворювання: легкий ступінь діагностовано у 53,91 \% хворих, середній - у 35,16 \%, тяжкий - у 10,94 \%. За поширеністю патологічного процесу на шкірі у 55,47 \% дітей спостерігалась обмежено-локалізована форма, в 35,16 \% - поширена, у 9,38 \% - дифузна. Поширеність клініко-мор- фологічних фрорм атопічного дерматиту в обстежуваних дітей була представлена таким чином: ексудативна - 9,38 \%, еритематозно-сквамозна-16,41 \%, еритематозно-сквамозна 3 ліхенісрікацією - 50,78 \%, ліхеноїдна - 22,66 \%, пруригоподібна - 0,78 \%. Перебіг атопічного дерматиту був ускладнений стафрілострептодермією у 17,19 \% випадків серед обстежуваних. Захворювання виникло на фоні уродженого іхтіозу шкіри в 2,34 \% дітей. Оцінювали тяжкість перебігу атопічного дерматиту в дітей за шкалою SCORAD, відмічали зростання індексу SCORAD від найнижчого значення при легкому перебігу до найвищих значень при тяжкому перебігу захворювання (табл. 1).

При аналізі показників клітинного імунітету виявлено, що загальна кількість лейкоцитів у дітей з атопічним дерматитом не перевищувала норми, але вірогідно зростала в разі тяжкого перебігу, і показники були вищими, ніж у контрольній групі (табл. 2).

В усіх вікових групах та при різному ступені тяжкості атопічного дерматиту спостерігалась тенденція до лімсроцитозу. Субпопуляційний склад лімфроцитів периферичної крові за кластерами диференціації мав певні особливості залежно від ступеня тяжкості захворювання. Так, у всіх пацієнтів з атопічним дерматитом відмічали вірогідне зменшення абсолютної та відносної кількості Т-лімфоцитів $\left(\mathrm{CD}_{3}\right)$, одночасно характерним було вірогідне зростання Т-лімфроцитів хелперів $\left(\mathrm{CD}_{4}\right)$ при вірогідному зниженні Т-лімфоцитів супресорів $\left(\mathrm{CD}_{8}\right)(\mathrm{p}<0,05)$, причому більш вираженим воно було при тяжкому перебігу недуги. Внаслідок дисбалансу між $\mathrm{CD}_{4}$ та $\mathrm{CD}_{8}$ лімфроцитами імунорегуляторний індекс зростав $(\mathrm{p}<0,05)$, причому його підвищення відбувалося співвідносно до зростання тяжкості атопічного дерматиту. Спостерігали статистично вірогідне збільшення кількості В-лімфоцитів $\left(\mathrm{CD}_{19}\right)$, а також збільшення кількості Т-лімфоцитів натуральних кілерів $\left(C_{16}\right)(p<0,05)$.

Отримані дані показників цитокінового статусу в дітей 3 атопічним дерматитом також достовірно відрізнялись від контрольної групи (табл. 3).

Аналіз середніх рівнів інтерлейкінів у дітей з атопічним дерматитом показав вірогідне зниження IL-2 при вірогідному зростанні IL-4, IL-6, IL-10 порівняно зі здоровими ( $<<0,05)$, що більш вираженим було при тяжкому перебігу

Таблиця 1. Середні значення індексу SCORAD залежно від тяжкості атопічного дерматиту в дітей (M士m)

\begin{tabular}{|l|c|}
\hline \multicolumn{1}{|c|}{ Тяжкість атопічного дерматиту } & Iндекс SCORAD, бали \\
\hline Легкий & $18,73 \pm 0,27$ \\
\hline Середньотяжкий & $49,87 \pm 1,62$ \\
\hline Тяжкий & $83,59 \pm 2,18$ \\
\hline
\end{tabular}

Таблиця 2. Субпопуляційний склад лімфоцитів у дітей з атопічним дерматитом залежно від тяжкості перебігу та дітей контрольної групи (M $\pm m)$

\begin{tabular}{|c|c|c|c|c|c|c|c|}
\hline $\begin{array}{c}\text { Тяжкість атопічного } \\
\text { дерматиту }\end{array}$ & $\mathrm{L}, \times 10^{9}$ 1/ת & $\mathrm{CD}_{3}, \%$ & $\mathrm{CD}_{4}, \%$ & $\mathrm{CD}_{8}, \%$ & $\mathrm{CD}_{16}, \%$ & $\mathrm{CD}_{19}, \%$ & $\mathrm{CD}_{4} / \mathrm{CD}_{8}$ \\
\hline Легкий & $6,25 \pm 0,37^{*}$ & $70,81 \pm 0,15^{\star}$ & $47,93 \pm 0,13^{*}$ & $22,88 \pm 0,12^{*}$ & $14,82 \pm 0,08^{\star}$ & $15,04 \pm 0,16^{*}$ & $2,09 \pm 0,12^{*}$ \\
\hline Середньотяжкий & $6,29 \pm 0,48^{*}$ & $71,58 \pm 0,21^{*}$ & $52,69 \pm 0,17^{*}$ & $18,88 \pm 0,21^{*}$ & $16,88 \pm 0,13^{*}$ & $17,77 \pm 0,14^{*}$ & $2,79 \pm 0,19^{*}$ \\
\hline Тяжкий & $8,75 \pm 0,80^{*}$ & $72,02 \pm 0,30 *$ & $55,68 \pm 0,26^{*}$ & $17,19 \pm 0,38^{*}$ & $18,61 \pm 0,32^{*}$ & $19,57 \pm 0,15^{*}$ & $3,24 \pm 0,32^{*}$ \\
\hline Контрольна група & $5,37 \pm 0,19$ & $72,37 \pm 0,12$ & $44,52 \pm 0,20$ & $27,84 \pm 0,22$ & $13,18 \pm 0,08$ & $12,05 \pm 0,13$ & $1,59 \pm 0,21$ \\
\hline
\end{tabular}

Примітка. Тут і в таблицях 2-4: * - вірогідність різниці між показниками дітей з атопічним дерматитом та дітей контрольної групи $(p<0,05)$. 
недуги. Під час дослідження рівнів INF- $\gamma$ відзначено достовірне їх зниження при атопічному дерматиті порівняно 3 контрольною групою $(p<0,05)$.

Дослідження показників гуморальної ланки імунітету у хворих і практично здорових дітей виявило тенденцію до дизімуноглобулінемії в дітей з атопічним дерматитом порівняно $з$ контрольною групою. Встановлено вірогідне зниження рівнів сироваткового IgA, особливо виражене при тяжкому перебігу захворювання, відмічали тенденцію до помітного підвищення концентрації сироваткових IgE та IgG у дітей з атопічним дерматитом ( $<<0,05)$, що корелювало зі ступенем тяжкості клінічного перебігу недуги. Аналіз концентрації гістаміну сироватки показав вірогідне його зростання при атопічному дерматиті (табл. 4).

Таблиця 3. Цитокіновий статус і рівень інтерферону-гамма у дітей з атопічним дерматитом залежно від тяжкості

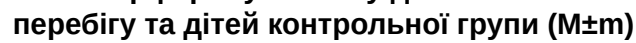

\begin{tabular}{|c|c|c|c|c|c|}
\hline $\begin{array}{c}\text { Тяжкість перебігу } \\
\text { атопічного дерматиту }\end{array}$ & IL-2, нг/л & IL-4, нг/л & IL-6, нг/л & IL-10, нг/л & INF- $\gamma$, нг/л \\
\hline Легкий & $3,62 \pm 0,05^{\star}$ & $1,33 \pm 0,02^{*}$ & $5,13 \pm 0,11^{*}$ & $7,30 \pm 0,12^{*}$ & $6,13 \pm 0,12^{*}$ \\
\hline Середньотяжкий & $3,07 \pm 0,04^{*}$ & $2,02 \pm 0,08^{*}$ & $8,28 \pm 0,20^{\star}$ & $9,99 \pm 0,34^{*}$ & $3,94 \pm 0,15^{*}$ \\
\hline Тяжкий & $2,10 \pm 0,14^{*}$ & $3,66 \pm 0,19 *$ & $16,85 \pm 0,99^{\star}$ & $16,75 \pm 1,70^{*}$ & $2,30 \pm 0,29 *$ \\
\hline Контрольна група & $5,65 \pm 0,15$ & $0,44 \pm 0,02$ & $1,99 \pm 0,14$ & $5,33 \pm 0,12$ & $8,14 \pm 0,10$ \\
\hline
\end{tabular}

Таблиця 4. Рівні сироваткових імуноглобулінів і гістаміну в дітей з атопічним дерматитом залежно від тяжкості

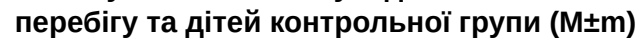

\begin{tabular}{|l|c|c|c|c|}
\hline Тяжкість атопічного дерматиту & $\operatorname{lgA}$, г/л & $\operatorname{lgE}, \mathrm{MO} / \mathrm{M} /$ & $\lg$, г/л & Гістамін, мкг/л \\
\hline Легкий & $1,54 \pm 0,05^{*}$ & $306,62 \pm 9,95^{*}$ & $10,26 \pm 0,08^{\star}$ & $2,02 \pm 0,10^{\star}$ \\
\hline Середньотяжкий & $1,45 \pm 0,32^{*}$ & $403,67 \pm 12,29^{\star}$ & $10,85 \pm 0,15^{\star}$ & $4,16 \pm 0,19^{\star}$ \\
\hline Тяжкий & $0,72 \pm 0,04^{*}$ & $784,90 \pm 65,93^{*}$ & $13,24 \pm 0,39^{\star}$ & $7,85 \pm 0,39^{\star}$ \\
\hline Контрольна група & $2,20 \pm 0,04$ & $27,85 \pm 2,10$ & $8,36 \pm 0,14$ & $0,50 \pm 0,04$ \\
\hline
\end{tabular}

ВИСнОВКИ. Для дітей з атопічним дерматитом характерні порушення клітинної ланки імунітету з розвитком дисбалансу між окремими субпопуляціями лімфоцитів. Перебіг алергодерматозу супроводжується зменшенням загальної кількості Т-лімфоцитів із зростанням кількості Т-хелперів та зниженням кількості Т-супресорів, відповідним підвищенням імунорегуляторного індексу, а також збільшенням кількості В-лімфроцитів і Т-лімфроцитів натуральних кілерів. Відмічено зміни в цитокіновій системі дітей: зниження IL-2, зростання IL-4, IL-6, IL-10, що залежало від тяжкості перебігу недуги. Аналіз показників гуморальної ланки імунітету в дітей, хворих на атопічний дерматит, показав тенденцію до дизімуноглобулінемії зі зниженням рівнів сироваткового $\lg$ А, підвищенням концентрації сироваткових $\lg \mathrm{E}$ та IgG. У дітей з атопічним дерматитом було виявлено зниження концентрації INF- $\gamma$ та зростання гістаміну сироватки крові.

Таким чином, з метою оптимізації діагностики атопічного дерматиту, оцінки тяжкості та динаміки клінічного перебігу,

\section{СПИСОК ЛІТЕРАТУРИ}

1. Беш Л. В. Атопічний дерматит у дітей / Л. В. Беш // Здоровье ребенка. - 2012. - № 2. - С. 37.

2. Беш Л. В. Атопічний дерматит у дітей: аналіз діагностичних і тактичних помилок / Л. В. Беш // Здоров'я України. - 2013. - Тематичний номер «Алергологія». - С. 52-53.

3. Давлетбаева Г. Р. Иммунные нарушения у детей с атопическим дерматитом в сочетании с хроническими заболеваниями / Г. Р. Давлетбаева // Вестник современной клинической медицины. - 2015. - № 4. - С. 56-64.

4. Дутчак Г. М. Особливості перебігу атопічного дерматиту у дітей / Г. М. Дутчак, О. Б. Синоверська // Здоровье ребенка. - 2011. - № 6. - С. 33-35.

5. Невозинская 3. А. Возможности контроля над течением атопического дерматита / 3. А. Невозинская, К. Т. Плиева, И. М. Корсунская // Consilium Medicum. Дерматология. 2016. - C. 49-53. есрективності проведеної терапії, подальшого прогнозу доцільно визначати показники клітинної і гуморальної ланок імунітету з визначенням концентрації субпопуляцій лімфроцитів, цитокінового статусу, рівня сироваткових імуноглобулінів, інтерферону, а також концентрації гістаміну в сироватці крові.

ПЕРСПЕКТИВИ ПОДАЛЬШИХ ДОСЛІДЖЕНЬ. Потребують подальшого вивчення імунні механізми патогенезу при атопічному дерматиті в дітей. Вважаємо доцільним подальше дослідження показників клітинного і гуморального імунітету, в тому числі субпопуляційного складу лімфоцитів, імуноглобулінів, цитокінового статусу, інтерферонів, концентрації гістаміну сироватки в дітей 3 атопічним дерматитом, 3 метою діагностики, контролю есрективності проведеної терапії та вивчення динаміки перебігу захворювання. Розробка та вдосконалення нових сучасних методів діагностики атопічного дерматиту дозволить індивідуалізувати і підвищити ефективність лікування та профрілактики цієї патології.

6. Охотникова О. М. Механизмы формирования и клинические особенности течения «аллергического марша» у детей / О. М. Охотникова // Здоров'я України. - 2010. - Тематичний номер (квітень). - С. 16-17.

7. Ruby Pawankar, Giorgio Walter Canonica, Stephen T. Holgate, Richard F. Lockey. On behalf of the World Allergy Organization (WAO), the authors of the WAO White Book on Allergy 2011-2012: Executive Summary express their gratitude to the charity, Asthma, Allergy, and Inflammation Research (AAIR) for support in the production of this publication. United States of America. - 2012. - 220 pages.

8. Severity scoring of atopic dermatitis: the SCORAD index. Consensus Report of the European Task Force on Atopic Dermatitis // Dermatology. - 1993. - Vol. 186 (1). - P. 23-31.

Отримано 27.07.16 